\title{
A1CF wt Allele
}

National Cancer Institute

\section{Source}

National Cancer Institute. A1CF wt Allele. NCI Thesaurus. Code C143032.

Human A1CF wild-type allele is located in the vicinity of $10 q 11.23$ and is approximately 86 $\mathrm{kb}$ in length. This allele, which encodes APOBEC1 complementation factor, plays a role in RNA binding and mRNA metabolism. 